\title{
Social Merchandising: Human Trafficking in Brazilian Soap Opera
}

\author{
Denise Avancini Alves ${ }^{1,2}$, Maria Helena Weber² \\ ${ }^{1}$ Pontifical Catholic University of Rio Grande do Sul (PUCRS), Porto Alegre, Brazil \\ ${ }^{2}$ Federal University of Rio Grande do Sul (UFRGS), Porto Alegre, Brazil \\ Email: deniseavancinialves@yahoo.com.br, mhelenaweber@terra.com.br
}

Received 31 October 2015; accepted 14 December 2015; published 17 December 2015

Copyright (C) 2015 by authors and Scientific Research Publishing Inc.

This work is licensed under the Creative Commons Attribution International License (CC BY). http://creativecommons.org/licenses/by/4.0/

(c) †) Open Access

\section{Abstract}

Human trafficking is one of today's largest shadow economies. This theme was included in plot of Salve Jorge, a soap opera in Brazil (broadcasted by Globo Network between October 2012 and May 2013). This article analyzes the social merchandising, an approach given to international human trafficking in entertainment venues of television, especially, from the telenovela Salve Jorge. The strategy of inclusion of social issues in the plots is recognized as social merchandising. So, it is in this privileged media space that the story of a social problem is also constituted. The study focuses on the discussion of the power of the telenovela to dramatize issues of public interest, having main broadcasting and audience of Salve Jorge. One seeks to question the maintenance and the impact of the subject of human trafficking as a dialogue between fiction and reality portrayed by Brazilian television. The show, Salve Jorge, is based on the real-life story of a Brazilian woman who was led to Israel and forced into prostitution. Therefore, human trafficking emerges as the central theme of this study over the main plot of Salve Jorge.

\section{Keywords}

Social Merchandising, Brazilian Soap Opera, Human Trafficking

\section{Introduction}

Human trafficking should mean the "recruitment, transportation, transfer, harboring or receipt of persons, by means of the threat or use of force or other forms of coercion, of abduction, of fraud, of deception, of the abuse of power or of a position of vulnerability or of the giving or receiving of payments or benefits to achieve the consent of a person having control over another person, for the purpose of exploitation. Exploitation shall include, at a minimum, the exploitation of the prostitution of others or other forms of sexual exploitation, forced labor or services, slavery or practices similar to slavery, servitude or the removal of organs” (UN, 10 2004, p; 
42). Generating, annually, more than 30 billion dollars, it is considered the third largest business in working capital in the world.

Human trafficking is a serious crime and one of today's largest shadow economies. It is one of the greatest violations of human rights today. Lured by the promise of a better life, people are recruited by criminal networks responsible for the third most lucrative illicit trade in the world, after the trafficking of drugs and weapons.

In terms of international classification, there are four traffic purposes recognized by the United Nations: sexual exploitation; removal of organs, tissues and body parts; slave labor; and servile marriage. For legal interpretation, trafficking can be configured as a kind of slavery, internationally coined under the term of "modern slavery". It is considered as a crime and is related to other criminal practices and human rights violations, serving not only the exploitation of slave labor, but also the international networks of commercial sexual exploitation, often linked to sexual tourism routes, with the involvement of specialized transnational gangs.

In Brazil, the issue was placed on the agenda by the federal government in 2004 with the publication of decrees to promulgate the UN convention against transnational organized crime and additional protocols. Since then, it has been discussed at the federal level with the launch of the National Policies to Counter Trafficking in Persons, as well as conducting symposiums to discuss the international problem. From 2005 to 2011, victims of trafficking in persons for sexual exploitation reached more than 450 cases mapped by the Ministry of Foreign Affairs, being considered as a business that presents variation accordingly to the world economy.

In media appropriation through entertainment, telenovelas take this issue as a central element. Human trafficking was addressed in Salve Jorge, written by Gloria Perez and broadcasted by Globo TV between October 22, 2012 and May 17, 2013. The inclusion of social issues in the plots of telenovelas is recognized as a social merchandising strategy. Therefore, it is in this privileged media space of fiction that the narrative of a social problem also constitutes itself.

In Brazil, the telenovela is part of one of the most popular narrative genres, settled in an effective way the routine of a large part of the Brazilian population, considering the high ratings and great penetration in the popular imagination.

Telenovela became the most popular product and one of the biggest sources of income in Brazilian television, especially at Globo Television. Moreover, the telenovela grew up addressing private life. Specifically Globo TV transformed the Brazilian telenovela into a consumer product for both national and international territories.

\section{Telenovela in Brazil}

Telenovela is a cultural product; it influences people's habits and customs, positively or negatively, by communicating, informing and entertaining. According to La Pastina (1994), telenovelas "have become very much a part of the fabric of the Brazilian society. It is hard to think of contemporary Brazil without thinking of telenovelas" because they are characterized as the main product of the culture industry, resulting from the television history and the culture of the country.

The consolidation of the telenovela as television's most popular and lucrative genre is closely related to a transformation in language by Brazilian authors, starting from the experience gained in radio and cinema. In Brazil, it is still possible to observe their great popular penetration, coupled with the fact that they have reached the foreign market, besides provoking controversy and mobilizing public opinion, being associated as the business card of the largest national television network.

"For nearly twenty years the telenovela has remained in that position, stating stylistic features and a way to make things which became known as 'Brazilian way', which mobilizes the national audience” (Hamburguer, 2011). The plot having its own time and being presented in chapter form causes the viewer to maintain a continuous interest. This seriality is one of the fundamental characteristics of the telenovela. The plot is presented to the viewer in daily episodes as "one story (or several interlaced and parallel narratives) which succeeds more or less linearly along all chapters" (Machado, 2001). Such characteristic is considered as a facilitator in that it establishes a routine that competes or occurs at the same time with and/or the other tasks of the home life and allows the viewer to track the sequence of the plot daily. Watching the telenovela becomes a ritual, a habit.

Brazilian telenovela, after achieving a considerable degree of credibility, has become a public space in which people debate representative issues of the country's own experience, thereby acting as a communication resource (Lopes, 2009). The telenovela, without abandoning the excitement and the characteristic pedagogical dimension of the melodramatic product, when approaching the limits of fiction with reality, has been being constituted with what Lopes (2009) designates as a communicative resource, bringing to the plot a repertoire of ref- 
erences recognized and shared by Brazilians. In this context, with the strategy of portraying contemporary social concerns in their plots, soap operas can promote or instigate discussions as to observe the Brazilian situation more accurately than in the newspapers.

Telenovela may act on the expansion of the audience capacities by using this narrative as a resource in everyday practices and interactions. Telenovela has become "a communication resource which, when activated, makes possible to share cultural rights, ethnic diversity and sociability, gaining greater awareness and motivation for practices against the conflicts and inequalities of Brazilian society” (Lopes, 2009).

In fiction, one cannot forget the true value, enhanced by Marques and Maia (2008) when they state, "even if we identify certain actions to exist only in the fiction realm, the feelings that move the characters, their gestures and intentions many times correspond to what we know about the world we inhabit”.

This authenticity at narrating, interpreting or reproducing discussions of contemporary society is strengthened by what has been called the social merchandising that, in transposing the (re)reading of the real for the fiction, brings elements that support the maintenance of an aesthetic that is able to gather the aspects of a melodrama. Misery, violence, poverty, trafficking, prostitution, drugs, schizophrenia are hard issues that melodrama incorporates according to its aesthetic characteristic, being able to soften or enhance its appeal in accordance with the degree of reception acceptance.

The aesthetic dimension of the product is also underlined by Weber (2000) who states that "the fact that most of the population has been inoculated by the aesthetics of television, it becomes more vulnerable and receptive to the more easily assimilated speeches, with more known references: compact, passionate, standardized, advertising" (Weber, 2000). Along with this point of view, there is the seductive power of media, because "the media, with logic and power equivalent to the state and the capital, distinguishes itself from these by agility, insight, and naive and transparent seduction capacity. It can relativize the real—the story-showing it in a less bleak outlook, more comfortable, providing alibis to the citizens about the impossibility of change, because of the complexity of power and politics" (Weber, 2000).

In addition, it is worth reflecting on the power of frameworks, especially for a population portion. "Citizens with low levels of information can make consistent decisions, but only when the public debate is relatively open to a wide range of interpretations of the political reality" (Porto, 2007).

"Brazilian social merchandising employs three main strategies: the presentation of engrossing fictional stories that activate empathy for real-life people suffering some form of injustice; the use of key characters to model desired messages or behaviors; and the incorporation of realia-such as references to or images of actual events - to tie the imagined world of the televised drama to the spectator's reality” (Atencio, 2014: p. 62).

This sui generis ability to synthesize the public and the private, the political and the domestic, news and fiction, male and female, is inscribed in the narrative of telenovelas, which combines formal conventions of documentary and television melodrama” (Lopes, 2009). The identification of real public figures with fictional characters are recurrent in telenovelas, there is a blurring of the boundaries between plots and real problems and the tendency towards a greater likelihood in storytelling. There is a continuous search for associating topics of public and private life referring to the merge of the public and private fields held by soap operas.

Telenovelas are studied further, especially Globo’s, a Brazilian television channel that has a hegemonic position before other media.

\section{Globo TV and Social Merchandising in Telenovelas}

Globo TV is the largest broadcaster in Brazil, balancing what is considered commercial success with artistic quality. According to OBITEL data (Ibero-American Observatory of Television Fiction), in Brazil, there are six national television broadcast networks, five being private_-Globo, SBT, Record, Band and Rede TV! — and one public, TV Brasil. In 2012, except for two, all produced and exhibited television fiction.

Regarding the individual audience, Globo remains in the lead with $40.7 \%$ of broadcast television. The broadcaster is considered the largest producer of television fiction in the country. There are about 2500 annual hours of telenovelas and programs, and 1800 annual hours of television journalism.

In 2012, among televisions tuned exclusively on television channels, Globo obtained $44.7 \%$ share. The station also confirmed its hegemony on programs, and the 47 most seen programs in 2012 were from Globo. In addition, over $80 \%$ of the hours of fiction produced and displayed in 2013 were telenovela, increasing its weight in the making of the broadcast programming of Brazilian television.

The dominant themes in the main fictions in 2012 refer to the following contexts: "family relationships, re- 
venge, ambition, adultery, identity revelations, disputes between social classes, racial, class and gender prejudice, child neglect, corruption” (Lopes, 2013: pp. 148-149). Globo TV has a consulting company responsible to the implementation of the social merchandising program in their soap operas. It is possible to see the evolution of the strategy of social merchandising by Globo during 1996 to 2005 (last ranking published), according Table 1.

In Salve Jorge, produced by Globo Network, the social merchandising was related to human trafficking.

\section{Salve Jorge and Human Trafficking}

Salve Jorge, written by Gloria Perez, debuted in prime time on Globo TV, on October 22, 2012, ending its display on May 17, 2013. With 179 chapters, the telenovela average audience was 33.6. Human trafficking is the social heart of the plot, opening the first chapter of the telenovela with scenes of an auction of the protagonist in Turkey (scenario-country where sexual exploitation is practiced with the tricked characters who lived in Rio de Janeiro). The victims of human trafficking for sexual exploitation are exploited by a gang with the 'justification' of debt acquired by the journey, family threat and restriction of access to documents, setting them up as illegal immigrants in that country.

The telenovela begins its first 30 seconds depicting images of Turkey. The scenes feature colorful plasticity, with pictures representing tourist areas of the country, especially the cities of Cappadocia and Istanbul. Right after, it presents the auction of a woman, who is recognized then as the protagonist of the plot, in a temporal projection of eight months of the narrative.

The scene is filmed inside a mansion, in a room, and, at the center, on a sort of platform, is the trafficked character-Morena, a single mother who lives with her mother and raises her child alone; this makes up the core of the plot (Figure 1). In the episode, she appears well made-up, dressed in elegant props and sensual clothing. Around, men of different nationalities (overlapping languages make the turn off the scene), wearing suits, smoking cigars, drinking and talking, admiring her beauty, but mostly the product she represents. Then, an interested man gets up and walks towards her in order to touch and smell the young woman. This same man makes the proposal and goes out with the trafficked woman who, in turn, shows revulsion and distress in the scene. The

Table 1. Number of scenes using social themes in soap operas on Globo TV (1996-2005).

\begin{tabular}{|c|c|c|c|c|c|c|}
\hline Period & Health & Sexuality & Drugs & Gender Issues & Social Issues & Total \\
\hline 1996 & 515 & 196 & 37 & --- & 323 & 1071 \\
\hline 1997 & 513 & 148 & 47 & 119 & 232 & 1059 \\
\hline 1998 & 355 & 145 & 304 & 143 & 510 & 1457 \\
\hline 1999 & 258 & 80 & 286 & 28 & 240 & 892 \\
\hline 2000 & 47 & 96 & 51 & 42 & 344 & 580 \\
\hline 2001 & 77 & 67 & 29 & 42 & 268 & 483 \\
\hline 2002 & 238 & 139 & 273 & 153 & 607 & 1410 \\
\hline 2003 & 208 & 159 & 129 & 257 & 601 & 1354 \\
\hline 2004 & 73 & 91 & 28 & 199 & 617 & 1008 \\
\hline 2005 & 277 & 544 & 63 & 135 & 532 & 1551 \\
\hline Total & 2561 & 1665 & 1247 & 1118 & 4274 & 10865 \\
\hline
\end{tabular}

Adapted from SCHIAVO, 2006 (p.4).

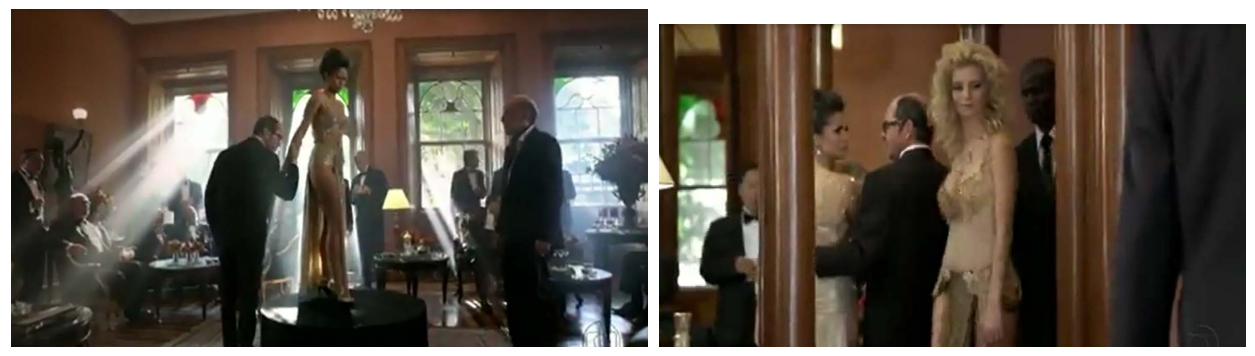

Figure 1. Frames of the first chapter of Salve Jorge. 
commodity is established. Soon after, another young woman enters the room, almost like a production line.

One can see that the first four minutes of Salve Jorge are intended to present the location where the plot will take place, with the climax being the auction of a trafficked woman. The auctioneer explains some features; among them, the age, they are over eighteen, and the fact that the trafficked woman is Brazilian. Such information reinforces or may be attached to the so-called guarantee of the legality of the activity (according to their age) and the nationality (Brazilian), considered an attribute because of the visibility of Latin women internationally.

International human trafficking has young Morena as its heroin, inhabitant of Complexo do Alemão (favela), in Rio de Janeiro, one of the main locations of the plot. She gets an offer to work in Turkey and, when she arrives in the country, she realizes that she had been trafficked, starting a struggle to get rid of the trafficking mafia and to see the head of the gang in Brazil, Livia Marine, arrested. Throughout the plot, Morena lives a complex love story with Theo, captain of the cavalry of the army, devoted to St. George, who wants to take on the relationship and raise as his the son of the young woman, Júnior.

The scenes displayed on December 4, 2012, show the moments experienced by Morena and the recruiter, then a friend, Wanda at the airport. Morena arrives in Turkey and comes across a group of foreign young women locked up. The girls, all deceived like her, are forced into prostitution in a nightclub. Angry, Morena attacks Wanda for having fooled her, becoming one of her main enemies (Figure 2).

The sequence of events demonstrates the crime of human trafficking for sexual exploitation: the profile of the victims (young women with financial difficulties), the emotional persuasion of the offenders to weave promises of a bright future and the incarceration in a closed nightclub or place without contact with the outside environment or the possibility to speak with relatives; who, at that time, can already be considered victims, because they are always coerced, besides all physical and psychological aggression.

The cast featured 91 characters plus extras to produce the most open scenes or those which reproduced the exploitation of the trafficked women. Regarding the locations, the main geographical areas of the plot were in Rio de Janeiro, especially in Complexo do Alemão, internationally, Turkey, mixing scenes of Cappadocia and Istanbul.

Concerning Complexo do Alemão's location, the view of the plot was marked by the favela pacification, with the presence of the cavalry of the Brazilian Army and its role in strengthening the process of UPPs (Pacifying Police Unit). Actors performed riding lessons, lived in the environmental army command to develop what is identified as laboratory preparation for telenovelas.

The geographical location of the narrative, then, is depicted in the first chapter, with shooting situations and the occupation of Complexo do Alemão (RJ). In comes also the cavalry of the army, which plays, as a result, the role of peacemaker in the favela. The scenes ${ }^{1}$ blend fiction with pictures of the news coverage of Globo TV, with audios of journalists and media images that accompanied the performance of military forces in real-time, which took place on November 28, 2010. At that time, as well as media coverage, residents of the community told what was happening there through social networks (Figure 3).

The chapters, displayed from Monday through Saturday, were, in average, 75 minutes long. The telenovela has been exported to many countries, including Portugal and African countries, where Globo Network already has partnerships serving their entertainment products.

In the construction of the plot what one sees, in fact, are the contexts already established in the dramaturgical product composition: "beautiful, passionate, young, virtuous, protagonist heroes; failures of one and the other are superficial and always justified. Their virtues are enhanced by the exaggeration: they are workers, steadfast,
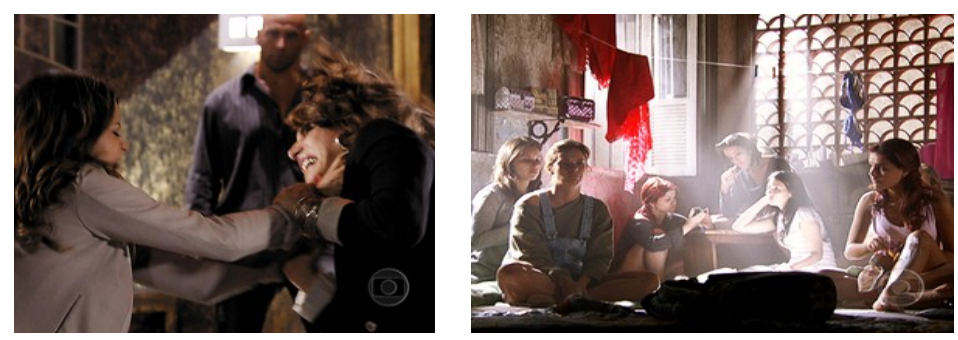

Figure 2. Frames of scenes showing trafficked people in Salve Jorge.

${ }^{1}$ The scenes are available on G1 website:

<http://globotv.globo.com/rede-globo/salve-jorge/v/o-exercito-entra-no-complexo-do-alemao/2203086/> Accessed in: September 10, 2014 


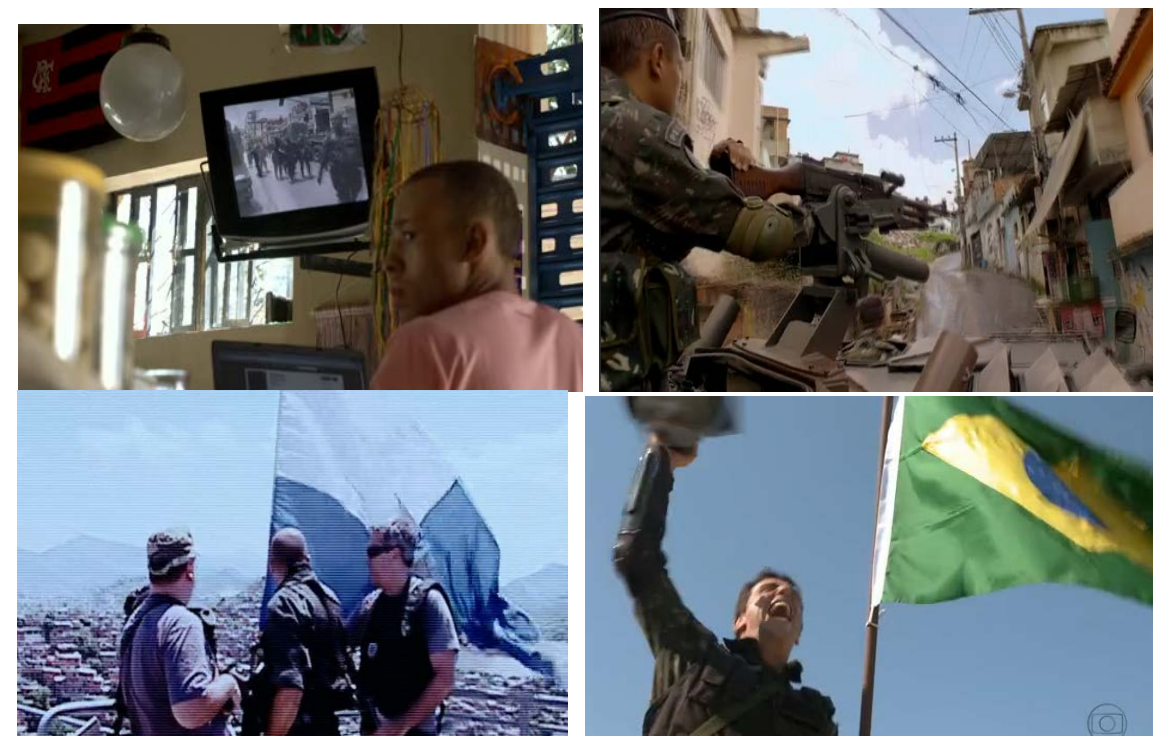

Figure 3. Frames of complexo do alemão ando of the army training.

good parents, fighters, honest, loyal, courageous, and are always looking good” (Pallottini, 2000: p. 07). In Salve Jorge, the formula is not replaced. The subplots are presented, bringing love affairs, disaffections, sexuality envisaged in the action of trafficking and in seduction, the different dimensions of social class, discussions and family conflicts, kindness, public actions in the scope of the Army and the Federal Police, and the victory of good against evil or the sense of justice done as a supposed happy ending.

Besides the sexual exploitation of human trafficking, the telenovela deals with trafficking in babies, rescuing, in the plot, the story of a character who was illegally adopted and discovers her true path along the evolution of the chapters. The action of the Federal Police, added to the military interventions, is set into the plot, showing the theme from the point of view of the mapping process of gangs and involvement of the international agenda, given the magnitude of the crime.

In terms of scenery, the police station of the Federal Police is constantly triggered, with the presence of delegate Helô or her staff that maps the human trafficking scheme, both of sexual exploitation and of illegal adoption of babies. The links are established and the gang begins to be unraveled along the plot (Figure 4).

International spheres are also represented by the action of Interpol - the International Criminal Police Organization - with the infiltration of an agent in the Turkish club, cooperating with the Federal Police in fighting the crime of trafficking. In the last chapter, the two teams come together and invade the establishment, arresting the gang and releasing the lured women.

In Salve Jorge, one can observe at least three dramatic arcs involving human trafficking: the victims of trafficking, the action of the gang and the actions of the Federal Police in tackling crime. These driven elements add in the configuration of Globo's social merchandising strategy. The dimension of reality in fiction, the correspondence with real situations, is evidenced by the telenovela by the display, at the end of some chapters, or even interacting with some characters throughout the plot (as in the case of the victims of trafficking in babies), of testimonials from relatives or victims of trafficking for sexual exploitation.

An example of this strategy is the testimony of the housekeeper Ana Lúcia Furtado, trafficked to Israel in 1998. She was a housekeeper and was the only breadwinner of her three children when, at the age of 24 , she received a proposal of what she dreamed to be a better future: working as a waitress in Israel. However, she ended up as a prostitute in a nightclub and was the inspiration for the author Gloria Perez to shape the character of the protagonist, Morena.

In the story of Ana Lúcia, one can see the description of how the allurement took place: "I was in a party in Madureira, my friend Kelly and I, when we met Rosana... She approached us, bonded with us, when later, in the late evening, she made us a proposal to travel abroad, to work as waitresses at a diner in Israel. In the meantime, she had bonded with us, gone to our houses, met our families, become our friend” (Globo, 2013).

For the first time after her rescue, which took place in 1998, Ana Lúcia volunteered to tell all her drama to 

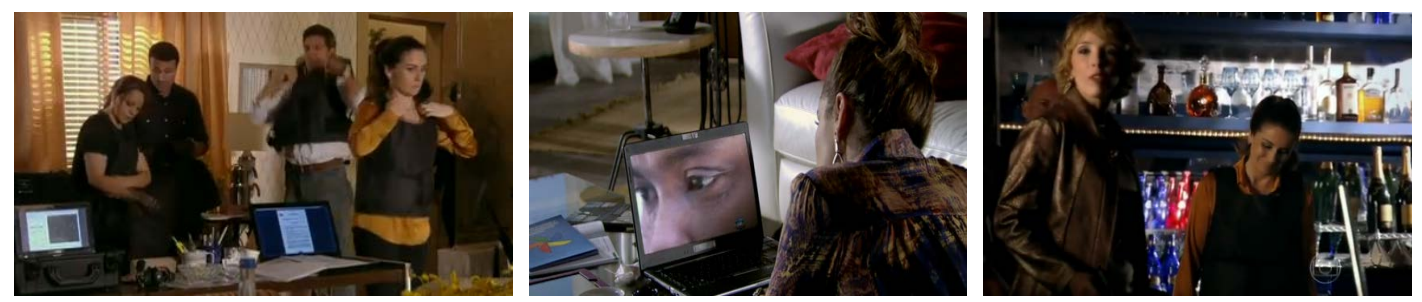

Figure 4. Scenes from the federal police in action in Salve Jorge.

Globo, in a testimony after Chapter 85, aired on January 28, 2013. Ana Lúcia tells how the three months being held by the gang were and about the murder of her cousin, Kelly Martins, who went to Israel with her and inspired the character Jéssica.

The story of Ana Lúcia is often more dramatic than the fiction lived by Morena (Figure 5). She says that the contact with Gloria Perez is frequent and that she often recognizes, among the dialogues of the telenovela, sentences she told the writer. Ana Lúcia says, "I even joke that what the telenovela shows is a dream if compared to what we lived. In comparison to what we went through".

In November 2012, about a month after the debut of the telenovela, other real testimonials were inserted, testimonials from people who had experienced or closely followed the drama of who was trafficked. One can observe in Globo's website a video with the testimony of João Borges, father of trafficked Simone.

In one of the testimonials, the father João Borges tells the story of Simone Borges, who went to Spain hoping to make money. However, it was a farce and she was forced into prostitution. (...) As in fiction, the kidnappers took all Simone's money, her passport and kept her in captivity. With her, there were approximately 10 and 15 other Brazilian women living the same drama. Simone died in the same year she went to Spain, in 1996 (Globo, 2013).

Simone traveled to Spain on January 22, 1996, you know. And then she picked up. ... So, I've got an invitation to go to Spain to work and I wanted to go there because the salary there is $\$ 1200$. When she arrived at the airport, they said: now the money you take from here (a thousand or so dollars), you give it to the pimp (...) to the woman who took you, and here you will work in a club (...) I did not know how many Brazilian women, 10 or 15 (...) all retained. They took the documents and forced them into prostitution (Globo, 2013).

The inclusion of testimonials on illegal adoption of babies is also observed. The disclosure of the NGO Missing in Brazil ${ }^{2}$ is performed during the episode (Figure 6) displayed on November 8, 2012 and December 3, 2012, the testimony of Lior Wilk, a babies trafficking victim.

He is a young Israeli who wants to find out who his Brazilian biological parents are. In the scene, with the support of technology, Aisha, a young woman who was sold as a baby, talks to the boy who was trafficked in 1985. He says he loves his adoptive parents, but wonders how his life would be if he had continued in Brazil. Such doubts are played in the plot also by the character, giving voice to the international problem.

Beyond the intention to anchor reality in the television product itself, Globo Network expanded the possibilities of transmedia theme display, offering to the public the website - on air during the airing of the novel coined as Disque Salve (Dial Save) created in partnership with the NGO Viva Rio, to give information and help answer questions about trafficking and exploitation of people.

In this project, the NGO Viva Rio was responsible for operating the Dial Save, with the making of all the theoretical content on the subject (Figure 7), both for the web service and the call center (training teams, training on the subject, among others).

According to Sandro Costa, coordinator of Save Dial at the NGO Viva Rio, the project recorded 456 cases in 22 weeks. In the 2013 work plan of the NGO, the project under the name Salve Jorge, had a budget estimated at R\$ 650,000.00 by Globo Network. It is inferred that such an investment is set as a social support, thus, liable to

${ }^{2}$ The non-governmental organization "Missing in Brazil" began in 1997, from the disappearance member of a given family. Since then, it formed a large network of volunteers and it never stopped growing. Thousands of cases that pass annually by the website registration show that $15 \%$ to $20 \%$ of the missing is from human trafficking. Available in:

<http://www.desaparecidosdobrasil.org/procuro-minha-mae/salve\%20jorge.jpg> Accessed in: May 14, 2015.

${ }^{3}$ The service remained available through the website: www.disquesalve.com.br and the call center: (21) 2555-3777 (Mon. - Sat., 5 pm - 11 $\mathrm{pm})$. 


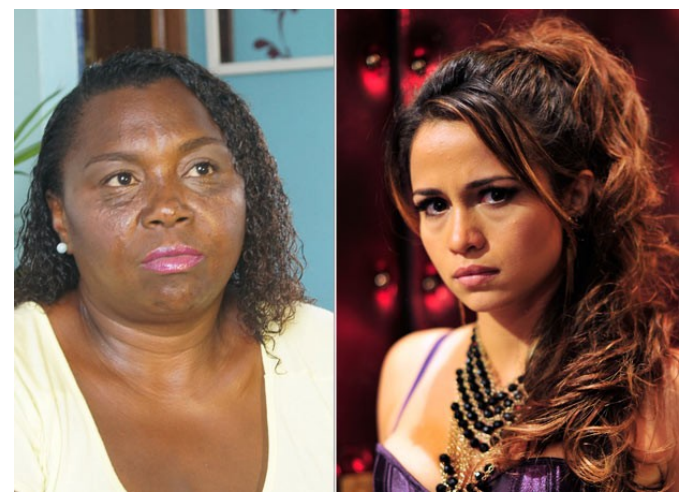

Figure 5. Trafficked women: in real life and in fiction.
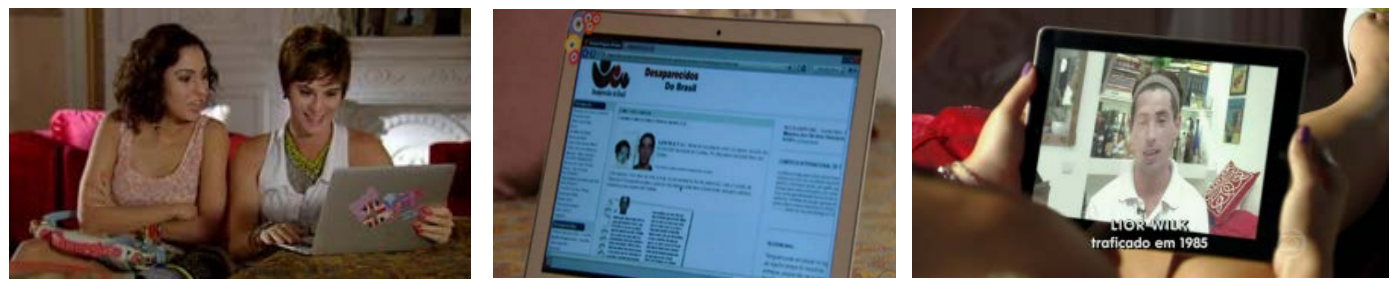

Figure 6. Scenes concerning illegal adoption.

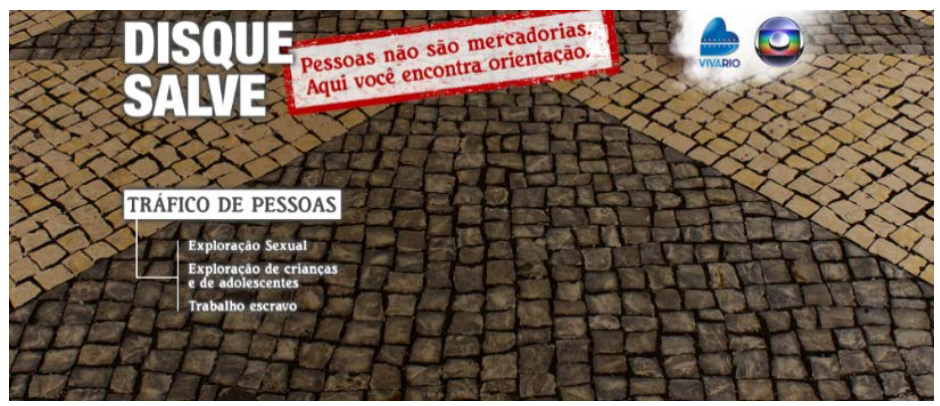

Figure 7. Printscreen from dial save’s website.

tax deduction. Therefore, it is clear that there is a transmedia ownership of the theme by the broadcaster, promoting its image as a company by linking social responsibility practices, besides increasing the visibility of their telenovela, guaranteeing an increase in audience.

In addition to the traditional serving of the telenovela on television, Globo Network has been investing in production of content for the web, seeking "the insertion and sustained growth of the Internet in Latin America and the accelerated use of virtual social networks ${ }^{4}$ in the region, especially Facebook and Twitter" (OBITEL, 2014). Following this trend, the broadcaster, in addition to the chapters available for subscribers of G1, offered exclusive content viewing on its website, making supplementary materials to the plot available in digital environment, expanding the supply of the theme and extrapolating the television schedule.

Among the materials observed, there is the composition of a comic book telling the journey of a character that did not have a happy ending, expected in melodrama. This is the trafficked Jessica, who played an important role in the discussion on human trafficking; she did not make it until the end of the plot, though, being murdered throughout the display of Salve Jorge.

To keep the memory of the character alive and to extend the dynamic possibilities of interaction with fiction, Globo published on the telenovela website the stylized story in comics format (Figure 8), with the following title and helpline: "The Drama of Jessica: review the story of the trafficked girl in comics". "Blonde fought hard

\footnotetext{
${ }^{4}$ According to OBITEL, "among fictional users, $82 \%$ were shown to be active in their visits to selected platforms, and their main activities were to comment, criticize and discuss with producers and other users, the fictional product content, this in relation to the participation in the official websites".
} 


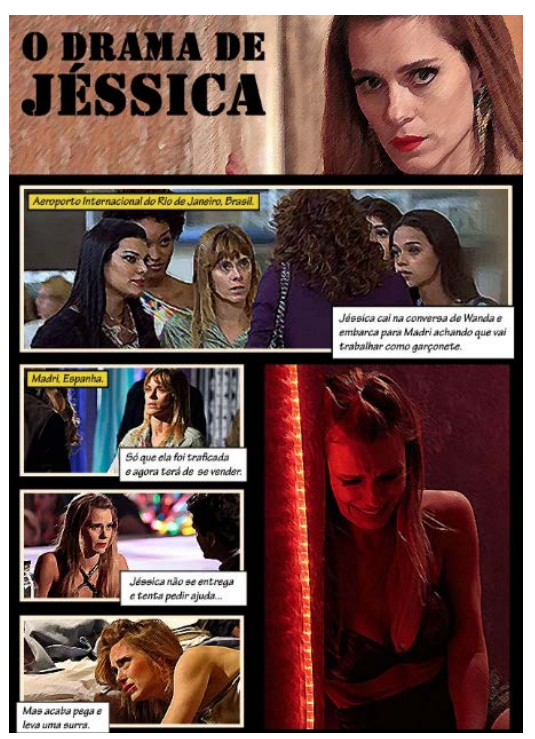

Figure 8. Image of the comic book: "The drama of Jessica”.

alongside Morena and ended up being murdered by Livia”.

The comic book summarizes the story of the character that, for having been inspired by a real case, takes on a new media space. In this case, Globo reproduced some scenes and developed an art of the frames, turning the serialization narrative into an edition specifically about a character. It shows a summary of Jessica's story and, by selecting her, it gives the character a parallel leading role, evidenced through a speech of contextual recovery through a narrator that translates the most emblematic scenes she lived in the plot.

In transposing the narrative text in a comic book of only character, the author offers her a degree of relevance, probably because she is an established actress, associated with the inspiration element of Kelly's life story, enticed and killed by a gang in Israel. Therefore, giving a new way of translating the narrative text into a comic book, it can transform the character Jessica into a superhero, commonly observed in this genre production. Moreover, in comic books with superheroes, there is the disguise feature to hide the identity of the protagonist. In this case, the cover is the very silence of the crime.

Another content offered in a transmedia way is in the Trafficking Dossier (Figure 9), which refers to a material available in the telenovela website that summarizes what the documentation of the characters involved in human trafficking in the plot would be.

According to the people responsible for production of content, there are three categories of bonding: trafficked, traffickers and victims. The website provides a brief overview of the profile of each character involved in the trafficking and complements the content with photos and videos.

The structure of the document refers to a visual aesthetic of police reports, with a technical data sheet of the characters, symbols and icons that refer to elements triggered by the legal sphere, as stamps and handcuffs.

Based on the drama of human trafficking observed in Salve Jorge, one can confirm that Globo Network, in its various derivations of melodrama, becomes an important element in building theme meanings in society, being responsible for giving light and voice to human trafficking issues, promoting its maintenance according to its marketing interest and rebuilding and reconfiguring social identities.

\section{Conclusions}

Television is an instrument to narrate history, society and to influence the ways of thinking of the public, mainly through the soap opera, which is considered as a cultural phenomenon in Latin America. The telenovela, as a popular genre, creates a public space to share experiences and national discussions (Lopes, 2012) and the representations in telenovelas tend to draw a parallel between the political and social realities. Salve Jorge is an example. Human trafficking has acquired importance, and, by giving voice and face to a story, and by inserting examples of lives stigmatized sexual identities or characters in violent situations, the soap opera reassures its role as a narrative capable of reflecting private dramas that, by gaining visibility into the public sphere, refer not 

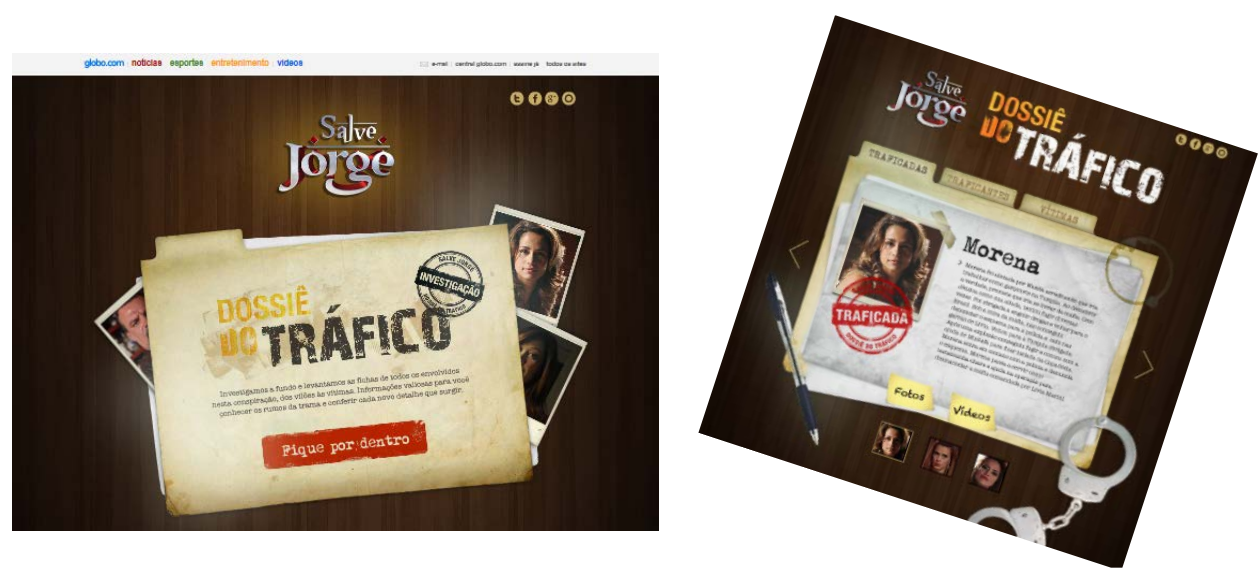

Figure 9. Trafficking dossier.

to a single individual, but to a collective that is placed in relation to the mediated experience of the other, producing a perception of reality.

The ideological work of the telenovela is in the way to provide a representation of reality, triggering real elements out of the fictional ones. In Salve Jorge, besides the debate of the subject, the melodrama has brought to social merchandising this dimension with the inclusion of real testimonials.

The social merchandising in telenovelas is effective in the promotion and visibility of the theme that the very public debates because it affects the emotional, the playful. It comes effectively with the inclusion of facts and real elements in fiction, strengthening the role of rapprochement with the portrayed social truthfulness. In addition, the theme is turned into commodities in situations that go beyond serving, through the broadcaster products available on digital platforms such as the Comic of Jessica or the Trafficking Dossier. In this sense, the power of the soap opera is in the dramatization of issues of public interest, which, by being romanticized, gains permanence or longevity in the media agenda.

\section{References}

Atencio, R. J. (2014). Memory’s Turn: Reckoning with Dictatorship in Brazil. Wisconsin: The University of Wisconsin Press.

Globo (2005). Commercial Formats Guide (trad. Manual de formatos comerciais). Negócios Globo.

Globo (2013). Website G1.

http://g1.globo.com/rio-de-janeiro/noticia/2013/02/mulher-que-inspirou-morena-de-salve-jorge-conta-o-drama-no-exterior $\underline{\mathrm{html}}$

Hamburguer, E. (2011). Telenovelas and Interpretations of Brazil (trad. Telenovelas e Interpretações do Brasil). Lua Nova: Revista de Cultura e Política, São Paulo, N. 82, 61-86,.

La Pastina, A. (1994). Research on Soap Operas in Latin America. (trad. Pesquisa sobre audiência de telenovelas na América Latina). Revisão teórica e metodológica in Revista Brasileira de Comunicação/INTERCOM, XVII, 17-37.

Lopes, M. I. V. (2009). The Soap Opera as a Communicative Resource (trad. A telenovela como recurso comunicativo). MATRIZes, 3, 21-47.

Lopes, M. I. V. (2012). Telenovela and Human Rights: Fiction Narrative as a Communicational Resource. In: A. V. Montie (Ed.), Comunicación y derechos humanos (pp. 175). International Association for Media and Communication Research (Alternatives Collection).

Lopes, M. I. V. (2013). Social Memory and Television Fiction in Ibero-Amercian Countries: Directory Obitel 2013 (trad. Memória social e ficção televisiva em países ibero-americanos: anuário Obitel 2013, Orozco Gomes, G. (Orgs.)). Porto Alegre: Sulina.

Machado, A. (2001) TV Taken Seriously (trad. Televisão levada a sério). São Paulo: Editora Senac.

Marques, Â. C., \& Maia, R. (2008). Emotional Appeal and Mobilization for Deliberation: The Homoerotic Link in Soap Operas (trad. Apelo emocional e mobilização para a deliberação: o vínculo homoerótico em telenovelas). In: Maia, R. (Org.). Media and Deliberation (trad. Mídia e Deliberação) (pp.380). Rio de Janeiro: Editora FGV.

Pallottini, R. (2000). Telenovelas: The Nices and the Bads (trad. Telenovela: os bons e os maus). In: Intercom-Congresso 
Brasileiro de Ciências da Comunicação. Manaus: Sociedade Brasileira de Estudos Interdisciplinares da Comunicação.

Porto, M. P. (2007). Television and Politics in Brazil: Globo and Interpretations of the Audience (trad. Televisão e Política no Brasil: a Rede Globo e as interpretações da audiência). Rio de janeiro: E-papers.

Weber, M. H. (2000) Communication and Political Spectacles (trad. Comunicação e espetáculos da política). Porto Alegre: Editora da Universidade, UFRGS. 